\section{Tinjauan} Pustaka

\section{HUBUNGAN PROFIL LIPID DENGAN PROGRESIVITAS DIABETES MELITUS TIPE 2}

\author{
Angiesta Pinakesty, ${ }^{1}$ Restu Noor Azizah, ${ }^{2}$ \\ 1,2Program Studi Pendidikan Dokter, Fakultas \\ Kedokteran, Universitas Muhammadiyah Surakarta, \\ Surakarta
}

\begin{abstract}
ABSTRAK
Pendahuluan: Diabetes melitus (DM) adalah salah satu penyakit tidak menular yang mengalami peningkatan dari tahun ke tahun. DM tipe 2 bukan disebabkan karena sekresi hormon insulin yang kurang, tetapi disebabkan oleh kegagalan sel-sel tubuh dalam merespon hormon insulin (resistensi insulin). Resistensi insulin ditemukan menjadi kontributor utama dislipidemia aterogenik. Dislipidemia pada DM berisiko 2 sampai 4 kali lebih tinggi dibandingkan non-DM. Meskipun dislipidemia memiliki risiko yang besar bagi penderita DM tipe 2, tetapi faktor risiko konvensional ini hanya menjelaskan sebagian (25\%) dari kelebihan risiko kardiovaskular pada DM tipe 2.

Metode: Tinjauan pustaka ini didapatkan melalui penelusuran buku teks dan hasil publikasi ilmiah dengan rentang waktu antara tahun 2006-2019. Data base yang digunakan sebagai media penelusuran publikasi ilmiah antara lain Google Scholar, National Centre of Biotechnology Information (NCBI), dan laman jurnal ilmiah kedokteran di Indonesia.

Pembahasan: Pada pasien DM tipe 2 yang tidak terkontrol, terjadi oksidasi low density lipoprotein (LDL) berlangsung lebih cepat yang diakibatkan oleh peningkatan kadar glukosa darah kronis. Kontrol glikemik sebagai penentu progresivitas DM ditentukan melalui pemeriksaan $\mathrm{HbA} 1 \mathrm{c}$. Kadar $\mathrm{HbA} 1 \mathrm{c}$ berhubungan dengan kadar trigliserida darah. Sedangkan, kadar trigliserida berhubungan dengan kadar kolesterol total dan kadar kolesterol HDL. Kadar HbA1c juga berhubungan dengan kadar kolesterol LDL.

Simpulan: Progresivitas DMT2 ditentukan oleh kontrol glikemik melalui pemeriksaan $\mathrm{HbA} 1 \mathrm{c}$ yang berhubungan dengan kadar trigliserida (korelasi rendah).
\end{abstract}

Kata Kunci: diabetes melitus tipe 2, dislipidemia, $\mathrm{HbA} 1 \mathrm{c}$, kontrol glikemik, profil lipid

\title{
CORRELATION BETWEEN LIPID PROFILE WITH TYPE 2 DIABETES MELLITUS PROGRESSION
}

\begin{abstract}
Introduction: Diabetes mellitus (DM) is a non-communicable disease that has increased from year to year. Type 2 DM is not caused by lack of insulin secretion, but is caused by the failure of the body's cells to respond to the hormone insulin (insulin resistance). Insulin resistance was found to be a major contributor to atherogenic dyslipidemia. Dyslipidemia in DM risks 2 to 4 times higher than non-DM. Although dyslipidemia has a large risk for people with type 2 DM, but these conventional risk factors only explain a portion (25\%) of excess cardiovascular risk in type 2 DM.

Method: Literature review was obtained through a search of textbooks and the results of scientific publications with a time span between 2006-2019. The data base used as a media for searching scientific publications includes Google Scholar, the National Center for Biotechnology Information (NCBI), and pages of medical scientific journals in Indonesia.
\end{abstract}


Discussion: In uncontrolled type 2 DM patients, the oxidation of low density lipoprotein $(L D L)$ occurs faster due to the increase in chronic blood glucose levels. Glycemic control as a determinant of DM progressivity is determined through $\mathrm{HbA1c}$ examination. HbA1c levels are associated with blood triglyceride levels. Meanwhile, triglyceride levels are associated with total cholesterol and HDL cholesterol levels. HbA1c levels are also associated with LDL cholesterol levels.

Conclusions: The progression of T2DM is determined by glycemic control through the examination of $\mathrm{HbA} 1 \mathrm{C}$ associated with triglyceride levels (low correlation).

Keywords: type 2 diabetes mellitus, dyslipidemia, HbA1c, glycemic control, lipid profil.

\section{PENDAHULUAN}

Diabetes melitus adalah salah satu penyakit tidak menular yang mengalami peningkatan dari tahun ke tahun. ${ }^{[1]}$ Menurut data dari International Diabetes Federation (IDF), prevalensi diabetes melitus (DM) di dunia sekitar $1,9 \%$ dan telah menjadikan sebagai penyebab kematian urutan ketujuh di dunia, sedangkan pada tahun 2012 angka kejadian DM di dunia sebanyak 371 juta jiwa dengan proporsi kejadian diabetes melitus tipe 2 sebesar $95 \%$ dari populasi dunia yang menderita DM. [2]

$\begin{array}{lrr} & \text { World Health } & \text { Organization } \\ \text { (WHO) memperkirakan } & \text { prevalensi } \\ \text { diabetes di Indonesia } & \text { berpotensi }\end{array}$
mengalami kenaikan drastis dari 8,4 juta orang pada tahun 2000 menjadi 21,3 juta penderita di 2030 nanti. [3] Potensi peningkatan kenaikan penderita DM didukung juga oleh data dari IDF yang memperkirakan kenaikan jumlah penderita DM dari 9,1 juta tahun 2014 menjadi 14,1 juta tahun 2035. ${ }^{[4]}$ Data dari Badan Pusat Statistik Indonesia ikut mendukung prediksi kedua data di atas. Diperkirakan pada tahun 2030 penderita diabetes di Indonesia meningkat menjadi 12 juta di daerah perkotaan dan 8,1 juta di daerah pedalaman. Meskipun terdapat perbedaan angka prevalensi, laporan ketiganya menunjukan adanya peningkatan jumlah penderita diabetes sebanyak 2-3 kali lipat pada tahun 2035. Daerah di Indonesia dengan prevalensi diabetes cukup tinggi, di antaranya Daerah Istimewa Yogyakarta (2,6\%), DKI Jakarta $(2,5 \%)$, Sulawesi Utara $(2,4 \%)$ dan Kalimantan Timur (2,3\%).[5] Diabetes melitus (DM) merupakan keadaan di mana metabolisme lipid, karbohidrat, dan protein terganggu di dalam tubuh, baik terjadi secara genetis maupun secara klinis dengan gejala berupa kurangnya daya kesanggupan (toleransi) karbohidrat..[6] Diabetes melitus, dibagi menjadi 4, yaitu DM tipe 1, DM tipe 2, DM gestasional, dan DM tipe lain. Diabetes melitus tipe 2 bukan disebabkan karena sekresi hormon insulin yang kurang, tetapi disebabkan oleh kegagalan sel-sel tubuh dalam merespon hormon insulin. Kondisi ini yang umumnya disebut sebagai "resistensi insulin". Resistensi insulin paling banyak disebabkan oleh karena obesitas, proses penuaan, dan minimnya aktivitas fisik. Resistensi insulin ditemukan menjadi kontributor utama dislipidemia aterogenik, seperti peningkatan kadar kolesterol total, trigliserida, kolesterol low density lipoprotein (LDL), dan penurunan kadar kolesterol high density lipoprotein (HDL). ${ }^{[7]}$

Dislipidemia pada DM berisiko 2 sampai 4 kali lebih tinggi dibandingkan non-DM. Toksisitas lipid pada DM lebih cepat memicu pembentukan aterosklerosis. Beberapa penelitian menyebutkan, kematian pada penderita DM paling banyak disebabkan karena aterosklerosis, yaitu sebanyak $80 \%$. Sebanyak $75 \%$ disebabkan karena penyakit jantung koroner (PJK) dan 25\% sisanya disebabkan karena stroke. ${ }^{[8]}$ Meskipun dislipidemia memiliki risiko yang besar bagi penderita diabetes melitus tipe 2, tetapi faktor risiko konvensional ini hanya menjelaskan sebagian (25\%) dari kelebihan risiko kardiovaskular pada DM tipe 2.[7] Dari beberapa hasil penelitian di atas, terdapat beberapa perbedaan mengenai risiko dislipidemia yang dijelaskan melalui profil lipid pada penderita diabetes melitus tipe 2. Dengan demikian, peneliti tertarik melakukan tinjauan pustaka lebih dalam mengenai 
hubungan profil lipid dengan progresivitas diabetes melitus tipe 2 .

\section{METODE}

Tinjauan pustaka ini didapatkan melalui penelusuran buku teks dan hasil publikasi ilmiah dengan rentang waktu antara tahun 2006-2019. Data base yang digunakan sebagai media penelusuran publikasi ilmiah antara lain Google Scholar, National Centre of Biotechnology Information (NCBI), dan laman jurnal ilmiah kedokteran di Indonesia. Terdapat lima jurnal ilmiah yang berkaitan dengan tinjauan pustaka ini

Tabel 1. Karakteristik Studi

\begin{tabular}{|c|c|c|c|}
\hline No & Penulis (Tahun) & $\begin{array}{l}\text { Desain Penelitian / } \\
\text { Responden }\end{array}$ & Hasil Penelitian \\
\hline 1. & $\begin{array}{l}\text { Fatimah, } \\
(2015)^{[2]}\end{array}$ & Artikel review & $\begin{array}{l}\text { Peningkatan Kejadian Diabetes } \\
\text { Melitus tipe } 2 \text { di timbulkan oleh } \\
\text { faktor faktor seperti riwayat } \\
\text { diabetes melitus dalam keluarga, } \\
\text { umur, Obesitas, tekanan darah } \\
\text { tinggi, dyslipidemia, toleransi } \\
\text { glukosa terganggu, kurang } \\
\text { aktivitas, riwayat DM pada } \\
\text { kehamilan. }\end{array}$ \\
\hline 2. & $\begin{array}{l}\text { Afandi, Muhammad } \\
\text { Rafli dan Ferdy } \\
\text { Royland Marpaung } \\
(2019)^{[7]}\end{array}$ & \begin{tabular}{lr}
\multicolumn{2}{l}{ Observasional, konsekutif, } \\
100 penderita diabetes \\
melitus tipe 2 yang \\
melakukan pemeriksaan \\
Apoprotein B, Apoprotein \\
A-I yang dihitung rasionya, \\
dan HOMA-IR secara \\
bersamaan \\
Laboratorium di \\
Parahita Klinik \\
Penelitian menggunakan \\
metode uji korelasi \\
Pearson dengan program \\
SPSS 22.0 for Windows.
\end{tabular} & 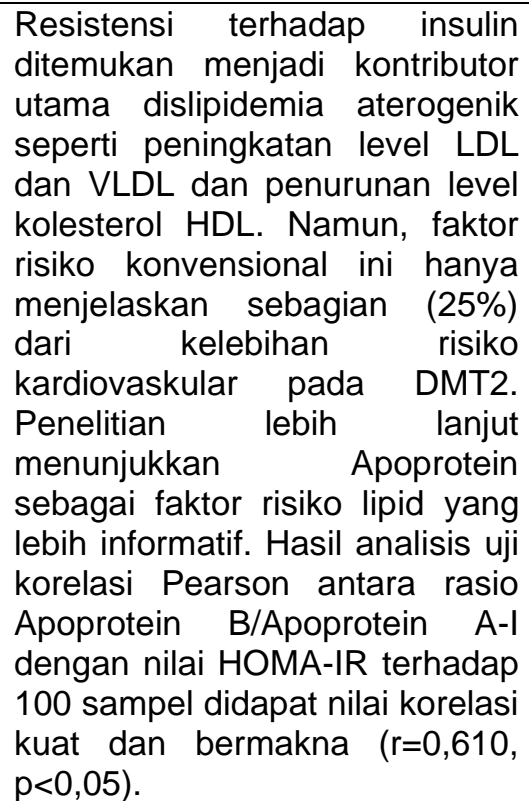 \\
\hline 3. & $\begin{array}{lr}\text { Lubis, } & \text { Novindy } \\
\text { Fahlawani, } & \text { Tapisari } \\
\text { Tambunan, dan } \\
\text { Dharma } & \text { Lindarto } \\
(2018)^{[8]} & \end{array}$ & $\begin{array}{l}\text { Analitik observasional } \\
\text { dengan pendekatan } \\
\text { potong lintang. Dilakukan } \\
\text { di Departemen Patologi } \\
\text { Klinik RSUP H. Adam } \\
\text { Malik Medan, terhadap } 50 \\
\text { sampel pasien laki-laki } \\
\text { yang terdiagnosa DMT2 } \\
\text { selama } 4 \text { tahun atau lebih } \\
\text { dan telah mengkonsumsi } \\
\text { obat lipid lowering agent } \\
\text { selama } 1 \text { tahun atau lebih, } \\
\text { tidak menggunakan obat- }\end{array}$ & $\begin{array}{l}\text { Pada uji t berpasangan, tidak } \\
\text { terdapat perbedaan bermakna } \\
\text { rasio HDL/LDL pada kedua } \\
\text { kelompok ( } \mathrm{p}=0.235) \text {. Pada uji } \\
\text { kolerasi didapati hubungan yang } \\
\text { signifikan antara lamanya } \\
\text { menderita DM dengan rasio } \\
\text { HDL/LDL pada kelompok DMT2 } \\
\text { tidak terkontrol ( } \mathrm{p}=0.0001) \text {, tetapi } \\
\text { tidak didapati hubungan yang } \\
\text { signifikan pada kelompok DMT2 } \\
\text { terkontrol }(\mathrm{p}=0.753) \text {. }\end{array}$ \\
\hline
\end{tabular}




\begin{tabular}{|c|c|c|c|}
\hline & & $\begin{array}{l}\text { obat yang meningkatkan } \\
\text { kadar gula darah atau } \\
\text { kadar lipid darah. }\end{array}$ & \\
\hline 4. & $\begin{array}{l}\text { Driyah, Srilaning, } \\
\text { Banundari } \\
\text { Rachmawati, dan } \\
\text { Herniah } \\
(2016)^{[18]}\end{array}$ & $\begin{array}{l}\text { Desain observasional } \\
\text { analitik dengan } \\
\text { pendekatan belah lintang } \\
\text { (cross sectional). } \\
\text { Responden } 30 \text { orang DM } \\
\text { dengan riwayat komplikasi } \\
\text { PJK diperiksa kadar } \\
\text { HbA1c melalui metode } \\
\text { ion-Exchange HPLC, } \\
\text { kadar kolesterol LDL } \\
\text { dengan metode kolometrik } \\
\text { enzimatik dan albuminuria } \\
\text { secara fotometrik. } \\
\text { Perbedaan antarvariabel } \\
\text { dianalisis dengan uji } \\
\text { korelasi Spearman. }\end{array}$ & $\begin{array}{l}\text { Terdapat hubungan positif } \\
\text { sedang antara HbA1c dengan } \\
\text { kolesterol LDL ( } \mathrm{r}=0.385 \text {; } \\
\mathrm{p}=0,018) \text {. Terdapat hubungan } \\
\text { positif kuat antara kadar HbA1c } \\
\text { dan albuminuria ( } \mathrm{r}=0.52 \text {, } \\
\mathrm{p}=0,004) \text {. Semakin tinggi kadar } \\
\mathrm{HbA1c} \text { semakin tinggi kadar } \\
\text { kolesterol LDL dan albuminuria. }\end{array}$ \\
\hline 5. & $\begin{array}{lr}\text { Driyah, Srilaning, } \\
\text { Lisyani BS, dan } \\
\begin{array}{l}\text { Kusmiyati } \\
(2019)^{[11]}\end{array}\end{array}$ & $\begin{array}{lr}\begin{array}{l}\text { Desain } \\
\text { analitik }\end{array} \begin{array}{r}\text { observasional } \\
\text { dengan }\end{array} \\
\text { pendekatan belah lintang } \\
\text { (cross sectiona). } \\
\text { Responden } 30 \text { orang DM } \\
\text { dengan riwayat komplikasi } \\
\text { PJK diperiksa kadar } \\
\text { HbA1c melalui metode } \\
\text { ion-Exchanger HPLC, } \\
\text { kadar kolesterol LDL } \\
\text { dengan metode kolometrik } \\
\text { enzimatik dan albuminuria } \\
\text { secara fotometrik. } \\
\text { Perbedaan antarvariabel } \\
\text { dianalisis dengan uji } \\
\text { korelasi Spearman. }\end{array}$ & $\begin{array}{l}\text { Hubungan negatif kuat antara } \\
\text { kadar HbA1c dan HDL, baik laki } \\
\text { laki maupun perempuan dengan } \\
\mathrm{r}=-0,647 \text {; } \mathrm{r}=-0,675 \text { dengan } \\
\text { tingkat kemaknaan } \mathrm{p}=0,017 \text {; } \\
\mathrm{p}=0,008 \text {. Sedangkan HbA1c } \\
\text { dengan LDL terdapat hubungan } \\
\text { negatif lemah, tetapi tidak } \\
\text { bermakna ( } \mathrm{r}=-0,352 ; \mathrm{p}=0,057) \text {. } \\
\text { Karena itu, pemeriksaan profil } \\
\text { lipid dapat dipertimbangkan } \\
\text { untuk memantau risiko penyakit } \\
\text { kardiovaskular khususnya bagi } \\
\text { mereka dengan gangguan } \\
\text { metabolisme gula darah. } \\
\text {. }\end{array}$ \\
\hline
\end{tabular}

\section{PEMBAHASAN}

\subsection{Profil Lipid}

Di dalam darah manusia ditemukan tiga jenis lipid, yaitu kolesterol, trigliserid, dan fosfolipid. Oleh karena sifat lipid yang susah larut dalam air, maka dibutuhkan suatu zat pelarut, yaitu suatu protein yang dikenal dengan nama apolipoprotein atau apoprotein. Senyawa gabungan antara lipid dan protein disebut lipoprotein. Terdapat 6 jenis lipoprotein pada manusia, yaitu $\mathrm{HDL}$, IDL, very low density lipoprotein (VLDL), kilomikron, dan lipoprotein a kecil $(\operatorname{Lp}(\mathrm{a})){ }^{\left[{ }^{1]}\right]}$

Sebuah profil lipid merupakan suatu ukuran risiko seseorang menderita penyakit kardiovaskuler. Pada pemeriksaan profil lipid diperiksa kadar kolesterol total, kadar trigliserida, dan kadar kolesterol HDL. Sedangkan, kadar kolesterol LDL didapatkan dari perhitungan hasil ketiga profil lipid di atas. Kelainan pada kadar keempat jenis lipid tersebut bisa menyebabkan keadaan dislipidemia. Kelainan fraksi lipid yang utama pada kondisi dislipidemia, antara lain peningkatan kadar kolesterol total $(\geq 240 \mathrm{mg} / \mathrm{dl})$, peningkatan kadar trigliserida $(\geq 200 \mathrm{mg} / \mathrm{dl})$, peningkatan kadar kolesterol LDL $(\geq 160 \mathrm{mg} / \mathrm{dl})$, dan penurunan kadar kolesterol HDL $(<40 \mathrm{mg} / \mathrm{dl})$. $^{[9]}$ Kondisi dislipidemia sering dijumpai pada penderita diabetes melitus. Hal tersebut dibuktikan bahwa terdapat hubungan antara rendahnya 
kadar kolesterol HDL dengan kenaikan plasma insulin. [2]

\subsection{Diabetes Melitus Tipe 2}

Diabetes melitus (DM) merupakan suatu penyakit kelainan metabolik yang ditandai dengan meningkatnya glukosa darah (hiperglikemi) disebabkan karena kelainan sekresi insulin, kelainan kerja insulin, atau gabungan keduanya. Menurut penyebabnya, DM diklasifikasikan menjadi 4, yaitu DM tipe 1, DM tipe 2, DM tipe lain, dan DM gestasional. Pada DM tipe 1 terjadi destruksi sel beta pankreas, sehingga menyebabkan defisiensi insulin absolut. DM tipe 1 disebabkan karena autoimun atau idiopatik. Sedangkan penyebab DM tipe 2 bervariasi, tetapi didominasi oleh resistensi insulin, sehingga menyebabkan defisiensi insulin relatif.[5]

Patofisiologi kerusakan sentral DM tipe 2 disebabkan karena resistensi insulin pada hati dan otot. Diperkirakan jauh sebelumnya, telah terjadi kerusakan beta pankreas dini dan berat. Selain, resistensi insulin pada hati, otot, dan sel beta pankreas, terdapat lima organ lain yang berpengaruh dalam patofisiologi DM tipe 2, antara lain jaringan lemak (meningkatnya lipolisis), saluran pencernaan (defisiensi inkretin), ginjal (peningkatan absorpsi glukosa), sel alfa pankreas (hiperglukagonemia), dan otak (resistensi insulin). ${ }^{[5]}$

Penegakkan diagnosis DM didasarkan pada kadar glukosa darah. Pemantauan hasil pengobatan menggunakan pemeriksaan glukosa darah kapiler dan glukometer. Terdapat empat kriteria diagnosis DM, antara lain: (1) pemeriksaan glukosa plasma puasa (tanpa asupan kalori minimal 8 jam) $\geq 126 \mathrm{mg} / \mathrm{dl}$; (2) pemeriksaan glukosa plasma $\geq 200 \mathrm{mg} / \mathrm{dl} 2$ jam setelah Tes Toleransi Glukosa Oral (TTGO) dengan beban glukosa 75 gram; (3) pemeriksaan glukosa plasma sewaktu $\geq 200 \mathrm{mg} / \mathrm{dl}$ dengan keluhan klasik; atau (4) pemeriksaan $\mathrm{HbA} 1 \mathrm{c} \geq 6,5 \%$ dengan menggunakan metode yang terstandarisasi oleh National Glycohaemoglobin Standarization Program (NGSP). Dengan catatan, $\mathrm{HbA} 1 \mathrm{c}$ tidak bisa digunakan sebagai alat diagnosis dan evaluasi pada kondisi anemia, hemoglobinopati, riwayat transfusi darah 2-3 bulan terakhir, kondisi-kondisi yang mempengaruhi umur eritrosit, dan gangguan fungsi ginjal.[5]

Kondisi hiperglikemi pada penderita DM memiliki peran sentral dalam terjadinya komplikasi. Keadaan hiperglikemia menyebabkan terjadinya peningkatan jalur poliol, peningkatan pembentukan Protein Glikasi non enzimatik, serta peningkatan proses glikosilasi itu sendiri. Proses-proses tersebut mengakibatkan peningkatan stres oksidatif, sehingga dapat memunculkan komplikasi berupa vaskulopati, retinopati, neuropati ataupun nefropati diabetika. ${ }^{[1]}$

\subsection{Hubungan Profil Lipid dengan Progresivitas Diabetes Melitus Tipe 2}

Mortalitas dan morbiditas pada pasien diabetes melitus tipe 2 paling banyak disebabkan karena penyakit kardiovaskuler, seperti penyakit jantung koroner. Salah satu faktor risiko terjadinya penyakit jantung koroner pada pasien diabetes melitus tipe 2 adalah profil lipid. ${ }^{[10]}$ Pasien diabetes melitus yang tidak dapat mengontrol kadar gula darahnya juga dapat berisiko menderita penyakit kardiovaskuler. ${ }^{[11]}$

Kelainan metabolisme karena resistensi insulin pada penderita DMT2 akan mempengaruhi metabolisme tubuh, di antaranya terjadi perubahan proses produksi dan pembuangan lipoprotein plasma. Terjadi penurunan efek insulin di jaringan lemak, sehingga proses lipogenesis berkurang dan lipolisis meningkat. Hal ini akan memicu terjadinya glucotoxicity disertai lipotoxicity yang menyebabkan terjadinya peningkatan kadar kolesterol LDL. Dalam keadaan kadar glukosa darah yang tinggi (hiperglikemi), oksidasi LDL berlangsung lebih cepat yang diakibatkan oleh peningkatan kadar glukosa darah kronis. ${ }^{[1]}$

Pada pasien DMT2 yang tidak terkontrol, terjadinya glikasi LDL lebih cepat. Struktur LDL pada DMT2 menjadi termodifikasi, teroksidasi, glikasi, menjadi kecil dan padat sehingga makin bersifat aterogenik. LDL merupakan lipoprotein yang berperan dalam pengangkutan fraksi lemak, terutama 
kolesterol dari hati menuju ke sel perifer. Peningkatan kadar kolesterol LDL plasma, terutama dalam bentuk oksidasi LDL (Ox-LDL), merupakan faktor penyebab utama terbentuknya plak aterosklerosis. Peningkatan kadar kolesterol LDL dalam darah inilah yang menjadi penyebab gangguan kesehatan terutama gangguan kardiovaskuler dan aterosklerotik. ${ }^{[12]}$

Hal yang menentukan progresivitas DM adalah kontrol glikemik. Pemantauan kontrol glikemik dilakukan dengan pemeriksaan HbA1c. Pemeriksaan tersebut bertujuan untuk memantau kadar glukosa darah selama 120 hari terakhir. ${ }^{[14]} \quad$ American Diabetes Assosiation (ADA) (2013) menyebutkan bahwa kontrol glikemik dikatakan baik (terkontrol) apabila $<6,5 \%$, kontrol glikemik sedang $6,5 \%-8 \%$, dan kontrol glikemik buruk (tidak terkontrol) $>8 \%$. Setiap kenaikan $1 \%$ kadar HbA1c maka angka kematian meningkat $25 \%$, komplikasi makrovaskuler meningkat $35 \%$, dan risiko infark miokard meningkat $18 \%$. ${ }^{[15]}$

Menurut penelitian Suastika (2008), kekuatan korelasi antara kendali glikemik dengan kadar trigliserida darah yang ditemukan tergolong rendah. Hal tersebut disebabkan karena masih banyak faktor yang mempengaruhi kadar trigliserida darah selain kendali glikemik. Menurut patogenesis DM tipe 2, durasi menderita DM tipe 2 juga memiliki kemungkinan menjadi faktor dominan yang meningkatkan kadar trigliserida darah. Berdasarkan hasil uji korelatif antara kadar trigliserida dengan kadar kolesterol HDL, ditemukan korelasi negatif bermakna yang menunjukkan semakin tinggi kadar trigliserida, semakin rendah kadar kolesterol HDL. Namun, kekuatan korelasinya termasuk rendah $(R=-0.103)$ karena bisa dipengaruhi faktor lain, seperti durasi durasi menderita DM, usia pasien, gaya hidup, dan lain-lain. Selain itu, ditemukan korelasi positif yang bermakna dengan kekuatan sedang antara kadar trigliserida dan kadar kolesterol total $(R=0.226)$. Dengan demikian, kendali glikemik secara tidak langsung juga memberikan pengaruh terhadap penurunan kadar kolesterol HDL dan peningkatan kadar trigliserida. ${ }^{16]}$

Hasil penelitian tersebut didukung oleh penelitian yang dilakukan oleh Priyadi (2015), yang menyatakan bahwa terdapat hubungan antara kendali glikemik dengan profil lipid pada pasien DM tipe 2. Hal itu terbukti dengan adanya korelasi yang bermakna antara kendali glikemik dengan kadar trigliserida dan adanya korelasi bermakna antara kadar trigliserida darah dengan kadar kolesterol HDL darah dan korelasi bermakna antara kadar trigliserida darah dengan kadar kolesterol total. ${ }^{[17]}$

Uji korelasi Spearman dilakukan oleh Driyah (2016) dari data subjek penelitian antara kadar $\mathrm{HbA1C}$ dan kolesterol LDL. Didapatkan hasil hubungan positif sedang $r=0.385$ dengan tingkat kemaknaan $p=0,014$, artinya semakin tinggi kadar $\mathrm{HbA1c}$ akan semakin tinggi kadar kolesterol LDL. ${ }^{[18]}$ Penelitian tersebut didukung oleh penelitian Meenu et al. (2010) dan penelitian Vinodmahato et al. (2011) yang menyatakan bahwa terdapat hubungan positif sedang antara $\mathrm{HbA} 1 \mathrm{c}$ dengan kadar trigliserida, kolesterol LDL, dan kolesterol very low density lipoprotein (VLDL). Pengaruh insulin terhadap produksi apolipoprotein di hati yang meregulasi aktivitas enzim lipoprotein lipase dan protein transfer ester cholesteryl (CETP) dapat menyebabkan dislipidemia pada DM. Selain itu, defisiensi insulin juga dapat menurunkan aktivitas herpatic lipase $(\mathrm{HL})$ dan produksi aktivitas lipoprotein lipase (LPL). ${ }^{[19,20]}$

\section{KESIMPULAN}

Berdasarkan pembahasan, progresivitas DMT2 ditentukan oleh kontrol glikemik. Kontrol glikemik dapat ditentukan melalui pemeriksaan $\mathrm{HbA} 1 \mathrm{c}$ yang berhubungan dengan kadar trigliserida. Dengan demikian, dapat disimpulkan jika profil lipid berhubungan dengan progresivitas DMT2, tetapi dengan korelasi rendah.

\section{DAFTAR PUSTAKA}

1. Sudoyo, Aru W, et al. "Diabetes Melitus di Indonesia". Buku Ajar IImu 
Penyakit Dalam. Jakarta: Interna Publishing, 2015.

2. Fatimah, R.N. "Diabetes Melitus Tipe 2". J MAJORITY. 4:5 (2015):93-99.

3. "The Top Causes Of Death." World Health Organization. 2017. 3 Maret 2020. <http://www. who.int/>.

4. "Consensus Statements On Issues Related To The Care, Management And Prevention Of Diabetes." International Diabetes Federation. 2015. 3 Maret 2020. $<$ https://www.idf.org/>.

5. PERKENI. Konsensus Pengelolaan dan Pencegahan Diabetes Melitus tipe 2 di Indonesia. Jakarta: PB PERKENI, 2015.

6. Price, A. Sylvia dan Lorraine Mc. Carty Wilson. Patofisiologi : Konsep Klinis. Proses-proses Penyakit, Edisi 6, (terjemahan). Jakarta: EGC, 2006.

7. Afandi, Muhammad Rafli dan Ferdy Royland Marpaung. "Correlation Between Apoprotein B/Apoprotein A-I Ratio With Homa Ir Value (Homeostatic Model Assesment Insulin Resistance) In Type 2 Diabetes Mellitus". Journal of Vocational Health Studies. 3:2 (2019):78-82.

8. Lubis, Novindy Fahlawani, Tapisari Tambunan, dan Dharma Lindarto. "Rasio HDL/LDL Kolesterol pada Penderita DM Tipe 2 yang Mengkonsumsi Obat Lipid Lowering Agent". Majalah Kedokteran Nusantara. 51:2 (2018):91-95.

9. PERKENI. Panduan Pengelolaan Dislipidemia di Indonesia. Jakarta: PB PERKENI, 2015.

10.Bonakdaran, S., Ebrahimzadeh S., dan Noghabi SH. "Cardiovascular Disease and Risk Factor in Patients with Type 2 Diabetes Mellitus in Mashhad, Islamic Republic of Iran". Eastern Mediterranean Health Journal. 17:9 (2011):640-646.

11.Driyah, Srilaning, Lisyani BS, dan Kusmiyati DK. "Korelasi Kontrol Glikemik dengan HDL dan SmallDense LDL pada Penderita Diabetes Melitus dengan Komplikasi Jantung Koroner di RSUP Dr. Kariadi Semarang, Jawa Tengah". Jurnal
Biotek Medisiana Indonesia. 8:1 (2019):67-75.

12. Noviyanti, Finisia, Eva Decroli, dan Susila Sastri. "Perbedaan Kadar LDLkolesterol pada Pasien Diabetes Melitus Tipe 2 dengan dan tanpa Hipertensi di RS Dr. M. Djamil Padang Tahun 2011". Jurnal Kesehatan Andalas. 4:2 (2015):545-550.

13.Bilouse, $R$ dan Donelly R. Buku Pegangan Diabetes. 4th ed. Jakarta: Bumi Medika, 2014.

14.Jonathan D. Schofield . Yifen Liu . Prasanna Rao-Balakrishna . Rayaz A. Malik . Handrean Soran. 2016. Diabetes Dyslipidemia, Diabetes Ther (2016) 7:203-219.

15."Position Statement: Standar of Medical Care in Diabetes-2013". American Diabetes Associations. 2013. 3 Maret 2020. $<$ https://www. diabetes.org/>.

16.Suastika, K. Dislipidemia pada Diabetes dan Sindrom Metabolik: Patogenesis dan Terapi, Dalam: 11 Kumpulan Naskah Ilmiah Obesitas, Sindrom Metabolik, Diabetes, Dislipidemia, Penyakit Tiroid. Bali: Udayana University Press, 2008.

17.Priyadi, Rheza dan Ratna Saraswati. "Hubungan Antara Kendali Glikemik dengan Profil Lipid pada Penderita Diabetes Melitus Tipe 2. E-Jurnal Medika Udayana. (2015). 1 Maret 2020

$<$ https://ojs.unud.ac.id/index.php/eum larticle/view/11957>.

18.Driyah, Srilaning, Banundari Rachmawati, dan Herniah Asti. "Hubungan Antara HbA1c Dengan LDL-K dan Albuminuria pada Penderita DM dengan Riwayat Komplikasi Jantung Koroner". Jurnal Biotek Medisiana Indonesia. 5:2 (2016):153-162.

19. Meenu, J et al. "Correlation Between Hbac Values And Lipid Profile In Type 2 Diabetes Mellitus". IJBAP. 2:1 (2010):47-50.

20. Vinodmahato, $\mathrm{R}$ et al. "Association Between Glycaemi Control And Serum Lipid Profil In Type 2 Diabetic Patients: Glycated Haemoglobin As Adual Biomarker". Biomed Research. 22:3 (2011):375-80 